\title{
Environmental investment as a tool for ensuring economic security of business entities: accounting aspects
}

\author{
Alexey Popov* \\ Ural State University of Economics, 8 Marta, 62, 620144 Ekaterinburg, Russia
}

\begin{abstract}
The paper is devoted to the issues of companies' investing environmental assets to ensure their economic security. The role of environmental investments in strengthening the potential of an economic entity is justified, which has a positive impact on the environmental security of regions and the state as a whole. The necessity of analyzing a group of environmental indicators of economic security of an economic entity is formulated. The author considers features and methods of evaluating the effectiveness of environmental investment projects and analyzes the system of legal regulation of forming accounting information used to evaluate the above effectiveness. The classification of environmental objects is given, their structure, principles of formation, recognition and evaluation being considered. The author summarizes promising areas of improving economic science in order to form more representative data to make well-grounded investment decisions, which will have a positive impact on the performance of economic entities, investment strategy and ensure sustainable development.
\end{abstract}

\section{Introduction}

In modern economic conditions characterized by development and modernization of industrial production, integration of industries, digitalization of economic processes and universal globalization, issues of environmental safety are becoming increasingly relevant since significant environmental problems related to global warming and climate change, loss of the biodiversity, desertification of territories and other adverse economic factors affecting the environment, growing environmental damage from emergencies and manmade disasters, air pollution, water pollution (underground water resources included), as well as biological resources of the world oceans affect the interests of the state, industry and citizens.

The current environmental situation in the Russian Federation reveals signs of a significant level of anthropogenic impact on the environment, the one caused by results of the past activities of enterprises included,

As noted in the "Fundamentals of State Policy in Environmental Development of the Russian Federation till 2030", approved by the President of the Russian Federation on April

* Corresponding author: prepodpopov@yandex.ru 
30,2012 , more than $54 \%$ of the urban population in more than forty regions are subject to the negative impact of air pollution, which exceeds the established standards. The volume of untreated industrial and domestic wastes dumped into open sources remaining significant and a negative trend associated with a decrease in the quality of soils and land prevailing, we observe losses in soil fertility, a decrease in the quality of agricultural land, deterioration in fertility and yields, and as a result, their removal from the fund of agricultural land, as well as a trend of desertification of a number of territories of more than 27 subjects of the Russian Federation on an area of more than 100 million hectares and increased amount of waste which is not involved in the subsequent economic turnover and dumped in the territories in violation of the requirements of environmental safety. Doctor of Economics, Professor Arkhipov writes that "from the perspective of the neo-industrial paradigm, GDP growth in modern Russia caused by inflation of petrodollars and the raw materials orientation of this economy leads to the depletion of natural resources and pollution of the environment and destroys the unity of biological and economic systems, extractive and manufacturing sectors, short-term and long-term public interests, accumulation and consumption." [1]

On the basis of the indicated prerequisites, the issues of investing in environmental facilities have proved to be of paramount importance at the present stage. These issues are discussed in detail in the works of Russian scientists-researchers Arkhipov A. I.[1], Khafilyev R. R.[2], Erokhina V. N.[3], Borlakova A. K.[4], Egorova M. S.[5], etc.

Professor Magaril (DSc) notes that "the actual problem is that when conducting an economic analysis of an investment project, the data obtained at the stage of environmental analysis are underutilized or are not used at all. In other words, environmental factors are not economically assessed and are therefore excluded from the analysis."[2]

In accordance with the urgency of the problems, the purpose of this work is to reveal the features of taking into account environmental factors when evaluating the effectiveness of investment projects in order to strengthen the economic security of business entities.

When describing the above features, we can't but mention the contribution of Professor Medvedeva to the development of methodological recommendations for the implementation of environmental and economic assessment of the effectiveness of projects of planned economic activities. She defines environmental and economic efficiency as " "an indicator characterizing the ratio of the overall economic benefits to losses from the project, including external environmental effects and related social and economic consequences affecting the interests of the population and future generations as a result of the implementation of the project." [6] The methodology proposed by this researcher implies the integration of the economic components (costs and benefits) of environmental activities into the program into the program of analysis of the effectiveness of investment projects.

A number of foreign researchers, in particular Newt S. [7], Cortazar G. [8], Lingart J. B. [9] and others address this problem and their development is of special scientific interest. In particular, Bonifant B.S. notes: "In the past, industrial enterprises opposed the introduction of environmental standards, fearing significant restrictions and high costs for compliance with environmental requirements. Today, however, many companies are moving towards improved business, increased productivity, and innovative technologies, while gaining additional competitive advantage from environmental investments. "[10]

The implementation of environmental investments is directly related to strengthening economic security of economic entities, which is justified by Belik I.S. [11], Kesyan Z.A. [12], Medvedev P.V. [13], Buletova N.E. [14], Vlasenko M.N. [15], etc.

Batova V.N. notes that "the problem of ensuring the economic security of entrepreneurship cannot be considered isolated from environmental aspects. This relationship should be based on a comprehensive analysis of the entire set of social, economic and environmental indicators in society. The urgency of these tasks is largely due 
to the fact that until now the environmental component has not been an independent element in the system of economic security. "[16]

Vysotskaya T.R. justifies in her work such an instrument of economic security as environmental liability insurance, which will reduce environmental risks if environmental damage is to be compensated. [17]

Thus, on the basis of the synthesis of the research results, the conclusion is made about the prevailing role of financial, personnel and social indicators of the economic security of the enterprise used to analyze and assess the level of the latter. However, we think these groups of indicators are not enough for a comprehensive assessment of the economic security of economic entities. In addition to traditional financial, human and social indicators, we suggest including environmental indicators, such as the volume of environmental investments made in total investments, the profitability of environmental investments, the amount of environmental damage and other indicators.

\section{Materials and Methods}

The research is based on universal general scientific methods of analysis, generalization, analogy, modeling, empirical methods of description and interpretation, as well as theoretical methods of formal and dialectical logic. The methodological basis for the research was the works of domestic and foreign scientists, normative legal acts in force at the time of writing of this work, international financial reporting standards, as well as draft regulatory acts to be implemented.

\section{Results and Discussion}

The main regulatory document of the Russian Federation used to assess the effectiveness of investments is the "Methodological Recommendations for Assessing the Effectiveness of Investment Projects," approved by the Ministry of Economy of the Russian Federation, the Ministry of Finance of the Russian Federation, Gosstroi of the Russian Federation on 21.06.1999 N VK 477. The specified recommendations:

1) unify the terminology and provide the indicators of the effectiveness of investment programs;

2) systematize and unify the rules and requirements that pre-project and project data must meet;

3) provide a methodology for calculating the performance indicators of investment projects in accordance with international standards and regulations;

4) justify the need to compare and critically analyze various options for technical, organizational and financial solutions to carry out a particular investment project;

5) take into account the specifics of launching some special projects that require an innovative approach and non-standard methods of evaluating effectiveness.

Table 1 shows options of the proposed methodology used to evaluate effectiveness of investment projects.

Table 1. Range of Investment Project Performance Assessment Methodology

Features of the methodology for evaluating the effectiveness of investment projects 
Table 1. Continued

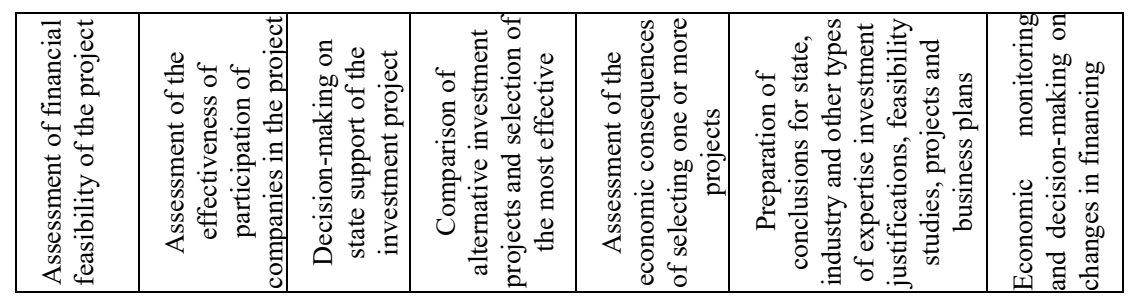

When doing investment analysis, one can use various methods of evaluating investments including:

1. Discounted cash flow methods, which include:

1.1 Net Present Value (NPV);

1.2 Internal Rate of Return (IRR);

1.3 Modified Internal Rate of Return;

1.4 Profitability (RR-Rate of Refund);

1.5 Discounted Payback Period (DPP).

2. Traditional assessment methods:

2.1 Accounting rate of Return (ARR);

2.2 Payback Period.

In order to assess the effectiveness of an investment project, environmental factors included, it is necessary to determine accurately the cash flows associated with investing in environmental facilities, cash flows associated with choosing alternative, less environmentally friendly options, and integrate the above data into the overall performance assessment system.

The data on the enterprise's environmental costs are generated in the accounting system, which provides complete and reliable information on the property used for environmental protection, environmental obligations and costs. In accordance with the new business conditions, economic entities are actively introducing an environmental accounting system, as a subsystem of accounting. The issues of formation of environmental accounting are discussed in the works of a number of domestic economists, such as Kozhukhova O. S. [18], Ilyicheva E. V. [19], Amanzholova B. A. [20], Saenko K. S. [21], etc. The dissertations on these problems defended by Cheprakova T. N. [22], Murueva E. K [23], and others deserve attention. We can't but mention the fact that the fundamental principles of environmental accounting in international practice were formulated in the previous century by Odum H. T.[24] and Akhnad I. J.[25], and later developed by Schaltegger S. [26]

The current four-level system of legal regulation of accounting at the first ( the highest) and the second (the level of federal and industry standards of accounting ) levels does not contain special rules of formation of information about the company's environmental activities in accounting.

The third-level legal document regulating the formation of financial information on environmental investments and environmental costs in accounting and in financial statements is the letter of the Ministry of Finance of the Russian Federation N PZ-7/2011 "On Accounting, Formation and Disclosure of Information on the Environmental Activities of a Company in Accounts ".

This letter presents the following classification of environmental accounting items, as shown in table 2 . 
Table 2. Classification of environmental accounting

\begin{tabular}{|c|c|c|c|}
\hline \multicolumn{4}{|c|}{ Items of environmental accounting } \\
\hline 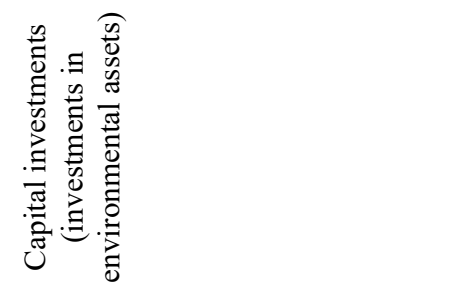 & 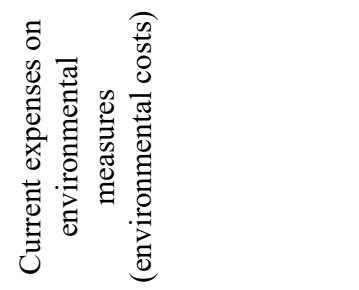 & 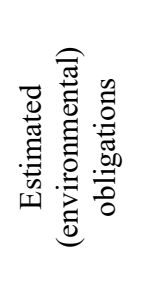 & 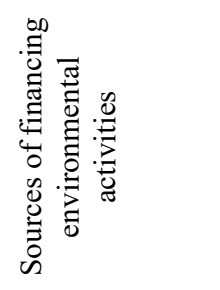 \\
\hline $\begin{array}{l}\text { - construction of facilities to protect air } \\
\text { from pollution by substances and } \\
\text { prevent climate changes (devices for } \\
\text { separating gas impurities and dust from } \\
\text { industrial gas; automatic air pollution } \\
\text { control systems; power generation } \\
\text { plants based on alternative sources } \\
\text { (wind and solar energy, biogas, thermal } \\
\text { waters, etc.);water protection and other } \\
\text { wastewater collection and treatment } \\
\text { facilities; for } \\
\text { - installing facilities } \\
\text { decontamination, for } \\
\text { processing of production and } \\
\text { consumption wastes; } \\
\text { - construction of anti-erosion hydro- } \\
\text { technical, anti-mudslide, anti-landslide, } \\
\text { anti-avalanche, anti-dump, including } \\
\text { coastal ones, facilities for terracing } \\
\text { steep slopes, recultivation of lands, } \\
\text { installing equipment for monitoring soil } \\
\text { and groundwater pollution, other actions } \\
\text { of protection and rehabilitation of lands, } \\
\text { surface and underground water; } \\
\text { - building facilities protecting } \\
\text { environment from noise, vibration and } \\
\text { other physical effects (screens, shields, } \\
\text { partitions, embankments, hedges); } \\
\text { - measures to ensure environmental } \\
\text { radiation safety aimed at reducing or } \\
\text { preventing the impact of radioactive } \\
\text { substances on the environment, } \\
\text { rehabilitation of contaminated areas, } \\
\text { neutralization and disposal of medium } \\
\text { and high radioactive waste, etc. } \\
\text { - research and development of } \\
\text { environmental equipment, installations, } \\
\text { structures, plants and facilities, } \\
\text { advanced environmental protection } \\
\text { technology, means of protecting } \\
\text { environment negative } \\
\text { anthropogenic impacts from }\end{array}$ & 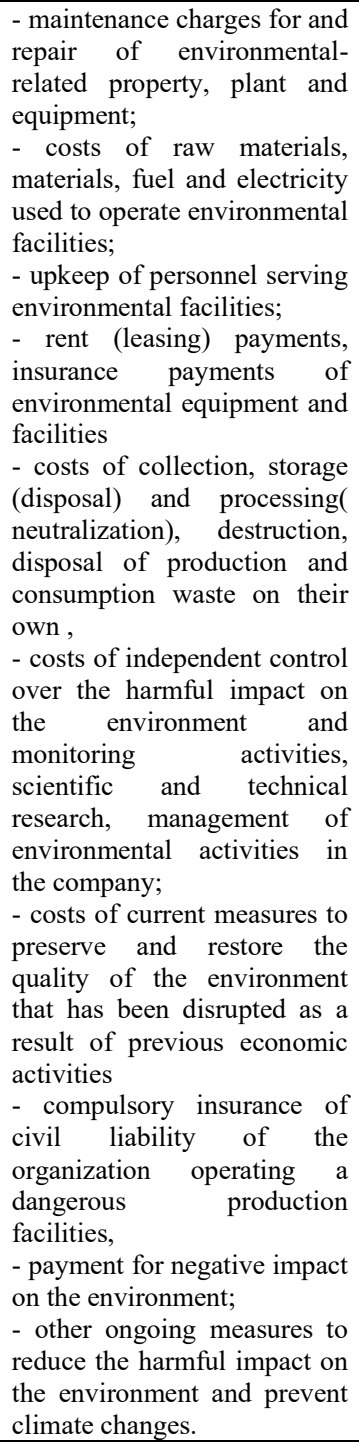 & $\begin{array}{l}\text { obligations } \\
\text { to restore } \\
\text { the } \\
\text { disturbed } \\
\text { ecological } \\
\text { system in } \\
\text { connection } \\
\text { with the } \\
\text { acquisition, } \\
\text { constructio } \\
\mathrm{n} \text { and } \\
\text { manufactur } \\
\text { e of } \\
\text { potentially } \\
\text { environmen } \\
\text { tally } \\
\text { hazardous } \\
\text { property, } \\
\text { plant and } \\
\text { equipment, } \\
\text { in particular } \\
\text { obligations } \\
\text { to recover } \\
\text { the costs } \\
\text { that the } \\
\text { company is } \\
\text { expected to } \\
\text { incur in the } \\
\text { performanc } \\
\mathrm{e} \text { of the } \\
\text { estimated } \\
\text { obligation } \\
\text { to dismantle } \\
\text { and dispose } \\
\text { of the } \\
\text { property, } \\
\text { plant and } \\
\text { equipment } \\
\text { and restore } \\
\text { the natural } \\
\text { resources } \\
\text { on the site } \\
\text { occupied }\end{array}$ & $\begin{array}{l}\text { - companies' } \\
\text { own sources of } \\
\text { financing } \\
\text { environmental } \\
\text { activities } \\
\text { - part of the } \\
\text { retained earnings } \\
\text { of the company } \\
\text { aimed at } \\
\text { environmental } \\
\text { activities } \\
\text { - state assistance } \\
\text { (subventions, } \\
\text { subsidies) } \\
\text { provided to } \\
\text { organizations for } \\
\text { environmental } \\
\text { activities } \\
\text { (environmental } \\
\text { control; } \\
\text { collection, } \\
\text { disposal of waste } \\
\text { and wastewater } \\
\text { treatment; } \\
\text { protection of flora } \\
\text { and fauna and } \\
\text { their habitat; } \\
\text { applied scientific } \\
\text { research in the } \\
\text { field of } \\
\text { environmental } \\
\text { protection; other } \\
\text { issues in the field } \\
\text { of environmental } \\
\text { protection) } \\
\text { - loans and } \\
\text { credits for } \\
\text { environmental } \\
\text { activities } \\
\text { (borrowed } \\
\text { sources) }\end{array}$ \\
\hline
\end{tabular}

We would like to consider the basic principles of evaluation of the above items of accounting and their impact on the generation of cash flows in order to assess effectiveness of environmental investment projects. 
The International Financial Reporting Standard (IFRS 16) "Fixed Assets" states that acquisition of fixed assets may be for safety or environmental purposes. Despite the fact that the purchase of these assets does not directly generate economic benefits (income) from their operation, it is often necessary for the economic entity to receive income from the use of its other assets. Such assets meet the criteria for identification as part of assets, as they allow enterprises to generate revenues from related assets that exceed the benefits potentially available in the event of a refusal to acquire such assets. For example, chemical industry can introduce new chemical technologies that ensure compliance with environmental regulations and regulations for manufacture and storage of hazardous chemicals, and therefore the associated modernization of production facilities is recognized as an asset, since without it the economic entity cannot produce and sell chemical products. Accordingly, it is advisable to distinguish this category of assets into a separate subgroup of fixed assets, called "environmental assets."

When assessing effectiveness of environmental investments, one should take into consideration the amount of costs for their implementation, excluding VAT and other reimbursable taxes. It is formed currently according to the accounting rules of accounting standard FAS 6/01 "Fixed Assets" in domestic practice, and according to the above IFRS 16 in international practice. As of today the process of reforming domestic accounting in accordance with international standards is very intensive, the program for developing federal accounting standards is in operation, annually being improved (at the moment - the program approved by Order of the Ministry of Finance of Russia of 05.06.2019 N 83n), which prescribes the date of entry into force of the new Federal Accounting Standard (FAS)"Fixed Assets" from January 1, 2022. Therefore, in this paper we will rely on international standards and cover the components of the costs included in the initial cost of an environmental asset under the rules of IFRS 16.

The initial cost of environmental assets includes:

1) the price of its purchase, including customs duties, fees and other payments and nonrefundable taxes on the purchase, minus trade discounts and adjustments;

2) all costs directly related to the transportation of the asset to the place of intended operation and bringing it into the condition necessary for use in accordance with the intentions of the management of the business entity;

3)the initial analytically generated value of the costs of dismantling and decommissioning an item of fixed assets and restoring the site occupied by it, for which the company assumes responsibility either when acquiring this item or as a result of its use for a certain period for purposes other than the production of inventories during this period.

The environmental assets directly related to the process of acquisition, construction and manufacture of the object also include:

- personnel remuneration costs arising directly from the construction or acquisition of an item of property, plant and equipment;

- site preparation costs;

- initial expenses of delivery and handling operations;

- installation costs;

- the cost of verifying the proper functioning of the asset, remaining after deducting the net earnings from the sale of products produced during the delivery of the asset to the intended location and bringing it to the required condition (for example, samples obtained when testing equipment);

- fees for professional services rendered and other costs.

These costs form initial cash outflows in order to calculate the net present value and other indicators for assessing the effectiveness of investments.

The current costs for environmental measures (environmental costs), the list of which is given in Table 2, are shown by the company in accordance with the current federal 
standard FAS 10/99 "Organization costs" as part of expenses for ordinary activities, or as part of other expenses, depending on the type, direction of expenditure and its compliance with the subject of the company's activities in the sum of recognized amounts. For example, the costs of environmental monitoring, testing and verification of products for compliance with environmental standards are unambiguously related to the costs included in the cost of products, work, and services. The costs of paying fines for violation of environmental legislation in accordance with paragraph 11 of FAS 10/99 are considered as other results of activity and are related to 91 "Other incomes and expenses." The specified current expenses are borne by the business entity in the process of implementation of the investment project, accordingly, cash flows on these operations are also subject to consideration in the performance assessment.

Environmental obligations as an integral part of the valuation obligations are formed in accordance with the rules of the federal accounting standard 8/2010 in the amount reflecting the most accurate monetary estimate of the costs required for the settlement of the formed obligation, for example, disassembly, dismantling, removal, disposal of equipment and other fixed assets, restoration of the initial properties of the occupied area, payment of environmental fees for the disposal of harmful and hazardous waste, etc.

When assessing the effectiveness of an investment project cash outflows under these obligations are made at the stage of its completion, therefore, when forming an estimated obligation, the estimated costs are subject to discounting using the discount rate used by the business entity.

When making environmental investments at the expense of their own sources of financing (retained profit), additional cash flows are not generated, accordingly, this fourth object is not taken into account in assessing the effectiveness of the environmental project, a positive cash flow being formed due to the funds of state assistance (subsidies received, subventions). The latter increases the net present value and this flow should be taken into account in calculations.

And when making investments in environmental assets at the expense of borrowed funds, it is necessary to follow the current FAS 15/08 "Accounting expenses on loans " to calculate efficiency since this standard prescribes the rules for showing basic expenses on loans, i.e. payable interest, as well as additional costs. At the same time, the interest to be paid is subject to capitalization (inclusion in the value of the investment asset), if the environmental asset is recognized as investment during the period of acquisition, construction and manufacture, while fulfilling a number of conditions specified in paragraph 9 of FAS 15/08, and otherwise relate to the structure of other expenses and reduce the financial result of the current period. It is therefore very important to identify the relationship of cash outflows to the project in order to estimate the cash flows used to calculate the effectiveness of the investment project.

\section{Conclusion}

Thus, the considered rules for assessing assets of environmental accounting, which form the cash flows necessary for calculating the effectiveness of investing environmental projects, will allow economic entities to choose the optimal project, carry it out and, thereby, strengthen their economic security indicators. Further research in this sphere should include the issues of reforming accounting and evaluation of environmental accounting assets in accordance with the Federal Accounting Standards development program since the international rules, on which the draft standards are based, need to be adapted to the domestic rules of accounting and conducting economic activities. 


\section{References}

1. A.I. Arkhipov, L.A. Kormishkina, L.P. Koroleva, Bulletin of the Institute of Economics of the Russian Academy of Sciences, 3 (2018)

2. R. R. Khalfiev, E. R. Magaril, Bulletin of USTU-UPI. Series Economics and Management, 2, 81 (2009)

3. V. N. Erokhina, T. V. Lesina, Science, 7(4) (2015)

4. A. K. Borlakova, SRRM, 6(75) (2012)

5. M. S. Egorova, Vectors of well-being: economy and society, 1(1) (2011)

6. O. E. Medvedeva, Methodological recommendations for the implementation of environmental and economic assessment of the effectiveness of projects of planned economic activities, 96 (2004)

7. C. Nehrt, Strategic Management Journal, 17(7), 535-547 (1996)

8. G. Cortazar, E. S. Schwartz, M. Salinas, Management Science, 44(8), 1059-1070 (1998)

9. J. B. Linhard, Journal of Safety Research, 36(3), 257-260 (2005)

10. B. C. Bonifant, M. B. Arnold, F. J. Long, Business Horizons, 38(4), 37-48 (1995)

11. I. S. Belik, Environmental and economic security (2013)

12. Z. A. Kesyan, Bulletin of the Adyghe State University, Economics, 4 (2010)

13. P. V. Medvedev, Problems of market economy, 1, 47-53 (2015)

14. N. Ye. Buletova, Ecological and economic safety: nature, content and problems of diagnostics in the regions of Russia (2013)

15. M. N. Vlasenko, Yu. N. Shedko, Business strategies, 2 (2017)

16. V. N. Batova, Yu. V. Ramzaeva, Development of ecological production in small business as a factor in improving the quality of life, Materials of the scientific-practical conference, 130-132 (2014)

17. T. R. Vysotskaya, Russian economic Internet journal, 2, 69-77 (2012)

18. O. S. Kozhukhova, Management of economic systems: electronic scientific journal, 3 , $112(2012)$

19. E. V. Ilyicheva, Fundamental research, 1, 66-67 (2009)

20. B. A. Amanzholova, N. V. Fribus, International accounting, 9(351) (2015)

21. K. S. Saenko, Audit and financial analysis, 5, 048-058 (2007)

22. T. N. Cheprakova, Accounting ecological accounting in the management system of agro-industrial complex organizations (2006)

23. E. K. Murueva, Environmental aspects of accounting (on the example of the forest sector of the economy) (2007)

24. H. T. Odum, Environmental accounting: emergy and environmental decision making, 707 (1996)

25. Y. J. Ahnad, E. Lutz, The World Bank Symposium / The World Bank, 118 (1989)

26. S. Schaltegger, R. Burritt, Contemporary environmental accounting: issues, concepts and practice (2017) 